\section{DIGITAL COMMONS \\ @ UNIVERSITY OF SOUTH FLORIDA}

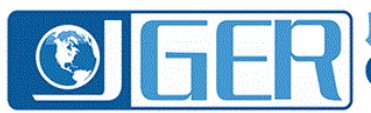

Journal of

Global Education and Research

\title{
The role of mental translation in learning and using a second/ foreign language by female adult learners
}

Julia Falla-Wood

Burman University, juliawood@burmanu.ca

Follow this and additional works at: https://digitalcommons.usf.edu/jger

Part of the Language and Literacy Education Commons

This Refereed Article is brought to you for free and open access by the M3 Center at the University of South Florida Sarasota-Manatee at Digital Commons @ University of South Florida. It has been accepted for inclusion in Journal of Global Education and Research by an authorized editor of Digital Commons @ University of South Florida. For more information, please contact digitalcommons@usf.edu.

\section{Recommended Citation}

Falla-Wood, J. (2018). The role of mental translation in learning and using a second/foreign language by female adult learners. Journal of Global Education and Research, 2(2), 98-112. https://www.doi.org/ 10.5038/2577-509X.2.2.1001

Corresponding Author

Julia Falla-Wood, Burman University

Revisions

Submission date: Jul. 30, 2017; 1st Revision: Nov. 3, 2017; 2nd Revision: Nov. 27, 2017; 3rd Revision: Mar. 30, 2018; 4th Revision: Dec. 29, 2018; Acceptance: Dec. 30, 2018 


\title{
The Role of Mental Translation in Learning and Using a Second/Foreign Language by Female Adult Learners
}

\author{
Julia Falla-Wood
}

\author{
School of Education \\ Burman University, Canada \\ juliawood@burmanu.ca
}

\begin{abstract}
The purpose of this study is to ponder some theoretical considerations concerning a predominant phenomenon of mental translation (MT) observed by second language teachers and learners in learning and using a second/foreign language. The sample available to the researcher consists of seven female adult learners speaking different languages. The choice of the sample is not related to the age level of the learners, but their English level (5-6) according to the Canadian Language Benchmarks. The research instruments used in this study are two compositions written on two occasions, during 2013-2015 and in 2016, a personal questionnaire, a strategy questionnaire, and a structured face-to-face interview. The results show that learners use mental translation as a strategy to compare and establish similarities and differences between first language (L1) and second language (L2). The learners create a translational zone where they put the results of the comparisons between L1 and L2 (MT product). The MT product becomes a procedural knowledge, stored in the long-term memory. To write in L2, the learners retrieve the information from their translational zone automatically and without awareness. The type of errors made in both written compositions shows how the influence of the mother tongue prevails despite the time living in the second language country, or the study within an academic system or with tutors. The use of mental translation as a strategy and as a product can explain the errors made by the learners in the second language and the prevalence of the influence of L1 in learning and using L2.
\end{abstract}

Keywords: second language acquisition, second language learning strategies, the role of mother tongue in second language acquisition

\section{Introduction}

Through the last six decades, researchers have undertaken numerous studies on Second/Foreign Language Learning/Acquisition (LL2). The results of studies, carried out on the nature and causes of errors, have shown different interpretations. The interpretation of these errors has generated concepts like positive or negative transfer (Carrió-Pastor, 2012; Faerch \& Kasper, 1986; Köhlmyr, 2003; Odlin, 1989; Schachter, 1992; Sharwood-Smith \& Kellerman, 1986; Towell \& Hawkins, 1994, interlanguage (Bialystok, 1982; Ellis, 1985, 1994; Krashen, 1982; Selinker, 1972), learning strategies (McLaughlin, 1987; Preston, 1989; Tomlin, 1990). It has also engendered different theories or models such as Automaticity (Anderson, 1992), Connectionism (Ellis, 2002), Input Hypothesis (Krashen, 1981), Competition Model (MacWhinney, Bates, \& Kliegl, 1984), Noticing Hypothesis (Schmidt, 1990), and Declarative/procedural model (Ullman, 2001). In all cases, the purpose of these studies was to gain a better understanding of the learning process of L2 
The studies of Anderson (1992), Bialystok (1982), Faerch and Kasper (1986), Hawkins (2001), Schmidt (1990), Selinker (1972), and Towell and Hawkins (1994) do not present, in an explicit way, the question of Mental Translation (MT). However, the concepts of transfer (positive and negative) could evoke the MT phenomenon. The role of MT could be more important than a simple strategy (O’Malley, Chamot, Stewner-Manzanares, Küpper, \& Russo, 1985a; O’Malley \& Chamot, 1990), a strategy used only at the beginning or at intermediate levels. Other studies (Conti, 2004; Macaro, 2006) undertaken on strategies show training on strategies improves the writing process of learners in L2. Empirical evidence collected through errors in written compositions from Carrió-Pastor (2012), Carrió-Pastor and Mestre-Mestre (2014), Köhlmyr (2003), Miliander (2003), Mourssi (2013), Pavlenko (2011), Rosén (2006), Ye (2004), and Zhang (2010), reveals that the influence of L1 is still an essential factor at different levels of competency. However, the results of Dulay and Burt (1974), Flynn (1984, 1987), and Krashen (1983) show a minimal or noninfluence of L1. In the cognitive approach, two positions are postulated. The first one is related to Chomsky (1965, 1976, 1980a, 1980b) and Lennenberg (1967). They posit there exists a genetic device for language acquisition, which is different and independent from other general cognitive mechanisms. The second one is associated with Anderson (1983, 1985), Bruner (1975), Piaget in Piatelli-Palmarini (1979), and Slobin (1973). They claim the general cognitive mechanisms are responsible for all cognitive activities comprising language acquisition. Falla-Wood (2017), after a meta-analysis of 60 studies on L2 undertaken within 40 years, found there was a link between the theoretical foundations underlying these studies and the interpretation of data. Those studies (Bley-Vroman, Felix, \& Loup, 1988; Clahsen, 1990; Meisel, 1997) for which theoretical foundations are operational cognitive strategies indicate an influence of L1, and those interrelated to universal sequences or order of acquisition display a partial or non-influence of L1 (Dulay \& Burt, 1974; Epstein, Flynn, \& Martohardjono, 1996; Krashen, 1983; Liceras, 1988a; Schachter, 1989, and White, 1985, 1986).

Certainly, other aspects could be involved in the learning process like individual characteristics. Watson, Cooked et al. (2016) believe a mixture of personality traits could have an impact on both anatomical and cognitive factors. Even though this is an interesting aspect to consider, it goes beyond the frame of this study. The relationship between the personality trait and the cognitive factor could be the object of further studies in LL2. However, first, it is essential to analyze how and when the learner uses the MT strategy; and second, determine if the use of the MT strategy could show how the influence of L1 does not disappear at different levels of competency.

\section{Literature Review}

For clarification, it is important to define specific terms. Translation, traditionally defined as the expression of a message in a different language from the one used to transmit the original message, has been the object of study from different perspectives: literary, philosophic, linguistic, and educational. From the educational aspect, teachers use translation as a teaching technique. MT has the same characteristics of translation, but it only happens in the mind of the learner. It is worth mentioning the intention of a translator, which is to produce a final product, oral or written, is not the same as the learner who does a mental translation to understand or produce sentences in L2. Kern (1994) is one of the few researchers to study the role of MT in reading comprehension. He defined MT as the "Mental reprocessing of L2 words, phrases, or sentences in L1 forms while reading L2 texts" (p. 442). Cohen and Hawras (1996) found similar results and stated translation facilitates reading comprehension in L2. They add this strategy benefits the advanced learners more than the intermediate level ones. Cohen (1995) stated people who speak two or more languages switch from one language to the other and they could execute this action involuntarily. 
Jiang (2004) claimed highly fluent speakers continue using their L1 concepts in L2 use. Dirix and Duyck (2017) analyzed the age of acquisition in the second language and the eye movement on bilingual readers. The results show if the translation of the L2 word was learned earlier, the L2 word was read faster.

O'Malley et al. (1985a) and O'Malley, Chamot, Stewner-Manzanares, Russo, and Küpper (1985b) in their research on strategies used in LL2, present 26 strategies divided into the following categories: cognitive, metacognitive, and social. In this classification, the MT belongs to the group of cognitive strategy and it is defined as the steps undertaken by learners to increase their comprehension and retention of L2. They believe a cognitive strategy frequently used becomes unconscious.

For this study, the definition of MT is a complex intellectual activity characterized by the mental passage from L2 to L1 or L1 to L2 on a continuum from conscious and voluntary to unconscious and involuntary. To be coherent with the role of MT in LL2, the following terms are defined: (a) Memory as it will contain elements related to the MT; (b) Intelligence, as it will intervene on components connected to the MT; and (c) Cognitive strategy and procedural knowledge as a mental activity and its dimensions, conscious or unconscious in LL2.

\section{Memory}

The results of studies undertaken in experimental psychology, cognitive psychology, and human pathology show there are several kinds of memory (Changeux, 1998; Laroche, 1998). Miller (1956) stated the short-term or working memory is limited to 20 seconds and limited capacity of $7 \pm 2$ items. This memory keeps the information active temporarily. Laroche (1998) divided the long-term memory to implicit memory (memory related to motor, cognitive and verbal skills), explicit memory which is divided into semantic memory (information related to facts, rules, or general knowledge acquired in life), and episodic memory (information related to personal events with a significant emotional value). Squire (2004) claims memory is a faculty of the mind composed of multiple systems directed by several operating principles. The most important distinction is between the declarative memory related to facts and events, and the non-declarative memory (procedural) related to unconscious skills and learning habits formed by experience. The terminology used to describe memory presents different functions; variations at an individual level are also possible since the neurophysiological characteristics of people are not necessarily the same. One can talk about different kinds of memory or one type of memory. Cardu (1996) stated a single memory exists and this memory can be adapted according to different situations.

In this study, it is not essential to determine if there is one or several kinds of memory but rather to make a distinction between what belongs to memory as a recipient of MT, and intelligence as an acting agent of MT.

\section{Intelligence}

Since the beginning of the discipline psychology, the nature of intelligence has been a controversial subject. Piaget (1961) stated intelligence should be understood as an operational capacity, a kind of generator or a motor where the activity consists in making mental operations on and with memory representations. From this point of view, intelligence creates constant relations between elements stocked in the memory and the construction and interpretation of new representations. These operations are conscious and unconscious. For some, intelligence is an intrinsically inherited faculty (Miele, 2002; Plomin \& Spinath, 2004; Spearman, 1904); for others, it covers all aspects 
of cognition (Gardner, 1993; Sternberg, 1985). Tassin (1998) added to the inherited faculty and cognition domain, the affective domain. He also claimed there are two ways of storing information in the brain: a rapid mode, called analogic, where the information is registered without being conscious (sensorial perception) and a slow mode, called cognitive, where the information is consciously analyzed before being stored.

In the frame of this study, intelligence operates and builds LL2, with the assistance of MT. The learner is conscious of the implementation and the use of strategies, but as these strategies are frequently used, they become automatic and are stored in the memory. In the case of the MT strategy, the learner is conscious of using it at the beginning of his/her learning process to compare L1 and L2. When this strategy is frequently used, it also becomes automatic, and the learner will use it as procedural knowledge.

\section{Cognitive Strategy and Procedural Knowledge}

In this study, it is important to consider the cognitive strategies as the steps used by LL2 learners to process elements for understanding or producing sentences in L2. These strategies will put in place or will process, in the memory, in a conscious way, an organized sequence of operations of intelligence, to reach an objective. The learner will use these strategies to understand and to produce sentences in L2. It is important to mention these strategies are not the only ones used in LL2. O'Malley et al. (1985a, 1985b) created a list of metacognitive, and social strategies as well. In O'Malley, Chamot, and Walker (1987) and O'Malley et al. (1990) tried to insert the cognitive, metacognitive, and social strategies into Anderson's Model (1983, 1985). The Adaptive Control of Thought (ACT) is a theory of learning, and it describes the structure of the memory. ACT differentiates three types of memory structures: declarative, procedural, and working memory. In this theory, all knowledge starts as declarative information, and procedural knowledge (generalization, discrimination, and strengthening) and consists of making inferences to an already existing knowledge. Faerch and Kasper $(1985,1986,987)$ applied these concepts of declarative and procedural knowledge in LL2. They claim declarative knowledge is the knowledge the learner acquires concerning the rules of L2 at different levels: phonological, morphological, syntactic, discursive, and pragmatic. They state declarative knowledge is consciously activated by intelligence, while the procedural knowledge is unconsciously activated by intelligence, as it has become automatic. Nyikos and Oxford (1993) claimed the cognitive processing strategies are unconscious and automatic, but they were conscious first. Rabinowitz and Chi (1987) stated strategies have to be conscious to be considered strategic, and if they become automatic and unconscious, they cannot be called strategies anymore. Schmidt (1994) pointed out if the strategy has become automatic and unconscious, then it is not a strategy, but a process. Ellis $(1994,2004)$ stated when learners cannot describe the use of a strategy verbally because they are no longer aware of using it, then, the strategy loses its significance as a strategy. It is, however, difficult to find, in the scientific literature, a term which will express a cognitive processing strategy and its unconscious character.

Concerning language, it is important to make a difference between creating a sentence which is the result of cognitive activities, and the use of elements required to produce that sentence. In other words, the sentence does not belong of itself to the memory or the language as a system. A sentence is a voluntary and instantaneous product of intelligence, using the representations and following the procedures and rules of the linguistic system which are stored in the memory. 


\section{Research Objective}

The purpose of this study was to examine in detail the samples of written compositions obtained through the ESLSAP (English Second Language Settlement Assistance Program) sponsored by the Canadian Government, and ETI (English Tutoring for Immigrants) sponsored by the British Columbia Provincial Government and North Island College. The written compositions from 20132015 of seven different learners with seven different mother tongues (Arabic, Chinese, Japanese, Korean, Portuguese, Russian, and Spanish) were compared with the samples obtained in 2016. This study could provide a better understanding of the L1 role in LL2, and a possible answer to the role of mental translation in LL2.

\section{Research Questions}

- Could MT as a cognitive processing strategy be present through all the learning process of L2?

- What are the theoretical considerations which could be drawn concerning the role of MT in LL2?

- Could theoretical considerations related to MT be applied to the Translational Hypothesis (Bibeau, 1979)?

\section{Methods}

This study was descriptive research, as it describes a predominant phenomenon observed by teachers and learners, that is, MT in learning and using L2. From this perspective, it is qualitative research, as its purpose is to analyze the phenomenon to establish some theoretical considerations concerning the presence of MT in LL2 and the use of L2, but without quantifying MT.

The method used to gather the information are two written compositions, one written questionnaire related to personal information, one written questionnaire concerning the strategies used in speaking and writing in English, and one structured face-to-face interview recorded for transcription.

\section{Sample}

The sample available to the researcher consists of seven female adult learners having different L1s. All the learners were female and wanted to improve their English Second Language skills. The choice of the sample was not related to the age of the learners but to their English level (5-6) according to the Canadian Language Benchmarks (2012). The Canadian Language Benchmarks (CBL) is a descriptive scale of language ability in English as L2. There are 12 levels on a continuum from the beginning to advanced level. CBL 5 is an initial intermediate ability, and CLB 6 is a developing intermediate ability where learners "Convey personal messages in short, formal and informal correspondence for a range of everyday social purposes, or an expanding range of everyday social purposes" (p. 193).

\section{Data Collection}

The learners wrote the compositions for forms one or two, task three from the Canadian Language Benchmarks Placement Test. The choice of form one or two is made according to which composition they wrote on their first assessment. The assessments took place during 2013-2015 and the summer of 2016. Some participants completed the initial evaluation in 2013, others in 
2014, and others in 2015. All of them completed the second assessment in the summer of 2016. The Canadian Language Benchmark personnel trained and qualified the assessor who performed both evaluations. During 2013-2016, the learners had English tutorial classes with volunteers twice a week for one and a half hours, except during the summer. All learners had legal status in Canada, three of them have a working permit, four of them have permanent residency; their stays varied from one to five years. All of them voluntarily agreed to participate in this study and signed a consent form after they had answered all their questions to their satisfaction. For this study, the diversity of the languages not being close to L2 is an exciting aspect, unintentionally determined by the sample available to the researcher. Could the phenomenon of MT be present in all these languages?

As for the correction of the written compositions in 2013-2015 and 2016, two native English speakers, both with majors in English corrected and indicated the errors made by the learners. The male corrector was an English teacher with a master's degree in Leadership and Administration. The female corrector had a bachelor's degree in English and a master's degree in Librarianship. The correctors did not communicate with each other. The errors were analyzed through a contrastive analysis of each L1 with L2.

\section{Findings}

The results are presented as follows: personal information questionnaire, errors, questionnaires on strategies, and face-to-face interviews.

\section{Personal Information Questionnaire}

Among the learners, five out of seven had a post-secondary diploma or degree, one had a high school diploma, and one had less than a high school diploma; all of them used English in daily communication. All of them acknowledged they could write simple compositions on different topics. They all believed they communicate better orally than through writing. Their percentage of daily oral communication varied between $30 \%$ and $90 \%$, and their written communication percentage ranged between $10 \%$ and $90 \%$.

\section{Errors}

All the learners compared both languages and established the differences they noticed between L1 and L2. These differences were the result of their observations and comments made during the face-to-face interview. It is worth mentioning the differences, observed by the learners, are sources of errors in their compositions. The researcher established a list of errors and identified them by the proper grammatical term and its function in the sentence (e.g., article, suffix, locative preposition, verb-agreement, etc.). These errors, validated by studies on each language (Arabic, Chinese (Mandarin), Japanese, Korean, Spanish, Portuguese and Russian) are discussed separately.

\section{Learner 1}

L1 is Arabic. She has been in Canada for four years. She made the same errors in both written compositions (Form 1), in 2015 and 2016. This learner studied English in elementary, high school, and university in Egypt. She speaks Arabic to her husband and children, but her children respond in English. The results of studies undertaken on contrastive analysis indicate the same kind of errors made by the learners in this study (Alhaysony, 2012; Al-Khuli, 1979; El-Sayed, 1982, Mourssi, 2013). 
1. The omission of plural nouns: In Arabic, there are two forms of plural: (a) The sound plurals divided into the sound masculine plural and the sound feminine plural. In this case, the plural is formed by the addition of a suffix to the singular form. (b) The broken plurals change the internal structure of the singular. In English, the plural is formed by adding "s" to the noun.

Example: "The friendly teacher will be patient with (the) student (missing "s"), if they make a mistake" (missing " $s$ ")."

2. Subject-verb agreement: Omission of the "s" on the third person singular. In Arabic, the third person singular never ends with an "s."

Example: "The teacher respect (missing "s") the student."

3. The omission of the verb "to be": In Arabic, there is no verb to be in the present tense. Example: "The issue not white or black" (missing verb to be)

4. The omission of the indefinite article: In Arabic, there is no indefinite article.

Example: "Some student (missing "s") like to have (missing "a") strict and demanding teacher.

5. The overuse of the possessive form: In Arabic, no difference is made between a possessive form and a noun construct.

Example: "Take care of the feeling of the student." (In the context, the term student should be in the plural form) instead of "Take care of the students" feelings".

6. There are difficulties with prepositions and phrasal verbs.

Example: "It can affect on the student in the future in the learning."

\section{Learner 2}

L1 is Mandarin. She had been in Canada for one year. She made the same errors in both written compositions (Form 1), in 2015 and 2016. The learner studied English in high school. She had been married to a Canadian for nine years when she had her first assessment. She speaks English with her husband and Mandarin with her son. The results of studies undertaken on contrastive analysis indicate the same kind of errors made by the learners in this study (Cheng, 2015; Hong, 1980; Lixin, 2015).

1. The omission of prepositions or incorrect use of prepositions: In Mandarin, the prepositions are not as precise as they are in English.

Example: "If the teachers are very friendly and relaxed for (should be around) me, they will push me (missing preposition "to") make progress."

2. An incorrect verb tense: In Mandarin, there is no verb conjugation to indicate tenses. Example: "If you enjoy to do (doing) something, you can do it better then (should be than) you (and you do not) get stress (missing "ed")."

3. The omission of plural forms: In Mandarin, there is no plural form for the nouns. The context determines if the noun is singular or plural.

Example: "doing homework, reading book" (missing "s").

4. Incorrect verb-subject agreement: In Mandarin, there is no verb conjugation or agreement. Example: "formal studies is important" (are)

5. The omission of articles: In Mandarin, there are no articles.

Example: "learning and understanding from life's experiences is (missing "the") most important." 


\section{Learner 3}

L1 is Japanese. She had been in Canada for three years. She made the same errors in both written compositions (form 1), in 2014 and 2016. The learner studied English in elementary and high school in Japan. She came to Canada in 2011, and her partner is Canadian. They speak English at home. She works full-time in a grocery store. The results of studies undertaken on contrastive analysis indicate the same kind of errors made by the learners in this study (Bryant, 1984).

1. The omission of the "s" on the plural forms: In Japanese, a noun on its own can be singular or plural.

Example: "both type (missing "s") of teacher"

2. The Subject-verb agreement: omission of the "s" on the third person singular. Japanese verbs do not change for person or number.

Example: "He understand (missing "s").

3. The omission of locative prepositions ("in", "to", and "at"): In Japanese, there are no prepositions.

Example: "I was grade five" (no preposition "in")

4. There is the omission of the indefinite and definite articles. In Japanese, there are no articles.

Example: "It was (missing "a") memory exercise." "Especially, (missing "the") grammar part was strict."

5. The incorrect verb tense: In Japanese, there are two divisions of time: Non-past (present and future) and the past.

Example: "But the teacher continue to taught" ("continued to teach").

6. The confusion with adjective endings in "ed" vs. "ing." In Japanese, words function as adjectives but are not syntactic adjectives.

Example: "I never got boring" ("bored").

\section{Learner 4}

L1 is Korean. She had been in Canada for five years. She made the same errors in both written compositions (form 1) in 2014 and 2016. The learner studied English in elementary and high school in Korea. She works full-time in a restaurant in Canada. She speaks Korean at home. The results of studies undertaken on contrastive analysis indicate the same kind of errors made by the learners in this study (Bauman 2006; Lardiere, 2009; Zheng \& Park, 2013).

1. The omission of the "s" on the plural forms: In Korean, a noun on its own can be singular or plural.

Example: "Some people strongly insist that strict teacher (missing "s") can help more."

2. The omission of the definite and indefinite articles: In Korean, there are no articles. Example: (missing "A") "Pleasant atmosphere is very important."

3. The Incorrect verb-subject agreement: In Korean, there is no conjugation of the verb using agreement with the subject.

Example: "There is (are) manners that... (There are manners which...)

4. The omission of prepositions: In English, prepositions are important. In Korean, some particles act like English prepositions.

Example: "Students can learn and focus more ("on") the class when emotionally comfortable." 


\section{Learner 5 and Learner 6}

Learner 5 is Portuguese, and Learner 6 is Mexican. They had been in Canada for three years. They made the same errors in both written compositions (Learner 5, form 1; Learner 6, form 2) in 2013 and 2016. The errors of these two learners are put together as the roots of both languages are similar. Learner 5 did not speak any English when she came to Canada. She is a high school student. She speaks English at school and home with her brother. She speaks Portuguese with her mother. Learner 6 is Mexican. She spoke very little English when she came to Canada. She married a Canadian in 2011. She speaks English at home, and she works full-time as a teacher's aide in a school. The results of studies undertaken on contrastive analysis indicate the same kind of errors in Portuguese and Spanish made by the learners in this study (Dulay \& Burt, 1973; Lanteigne, 2006; White, 1985).

1. The Subject-verb agreement in omitting the "s" on the third person singular: In Portuguese and Spanish, the verb form changes for each person, and in English, it changes only for the third person singular. In Portuguese and Spanish, the third person singular will never end with an "s."

Example: "He feel (no $s$ ) forced to do that."(Portuguese learner)

"Writing about this make (missing "s") me think...) (Spanish learner)

2. The omission of the subject is allowed in both languages, but not in English.

Example: "I said that is (no it) best... (Portuguese learner)

"Before come (coming) to Canada, (I) took some English classes." (Spanish learner)

3. The use of the infinitive form instead of the gerund required in English.

Example: "People said that learn (learning) a new language..." (Portuguese learner)

"Be (Being) competitive give us..." (Spanish learner)

4. The adjective placed after the noun instead of before the noun as it is required in English. Example: "People have their own opinion about how to learn best (best learn)..." (Portuguese learner)

"Our work good... (good work)"

5. The plural form "s" used with both the adjective and the noun while in English, only the noun takes the plural form.

Example: "Others teachers" (Portuguese learner)

"Speak with others persons" (Spanish learner)

\section{Learner 7}

Learner 7 is from Kazakhstan, but Russian is her mother tongue. She had been in Canada for one year. She made the same errors in both written compositions (form 1) in 2015 and 2016. The learner studied English in elementary, high school and university in her country. She speaks English at work, and she works full-time as a caregiver. The results of studies undertaken on contrastive analysis indicate the same kind of errors made by the learners in this study (Bondarenko, 2014; Rozovskaya \& Roth, 2010).

1. The omission of indefinite and definite articles: In Russian, there are no articles. Example: (missing "A") "Doctor is responsible for life." "Choose (missing "the") wrong way."

2. The incorrect use of prepositions or omission of prepositions: In Russian, some cases require a preposition while in English, in those cases, it is not necessary, and vice-versa. 
Example: "Parents gave their life (lives) (missing "for") the most treasurable (missing a noun) that they have."

3. The omission of plural forms: In Russian, the plural form can take different endings. Example: "Structure of their personality" (personalities)

4. The subject-verb agreement in omitting the "s" on the third person singular: In Russian, the verb form changes for each person, and in English, it changes only for the third person singular. In Russian, the third person singular will never end with an "s."

Example: "The teacher give (missing "s") (missing "the") wrong direction."

5. The use of the infinitive form while in English the gerund is required.

Example: "I think to be (being) a teacher is (missing "a") true vocation."

All these learners are functional in English; all but two learners studied English in their home countries; they have lived in Canada for several years; they had daily contact with the language, and they made the same mistakes in the two compositions written on two different occasions with an interval of at least one year in between. Those errors, as presented above, indicate an influence and presence of L1 in both compositions.

\section{Questionnaire on strategies}

As for the questionnaire on strategies, there were 15 questions, and the learners answered according to four possible criteria: always or almost always, often, sometimes, never or almost never.

1. I think first of what I want to write in my language, and then I write the sentences in English.

2. I use only words that are similar to my native language.

3. I use simple expressions because I do not want to make mistakes.

4. I pay attention to grammar and word order because it is different in my language.

5. I take my time to express what I want to write.

6. I correct myself when I notice that I have made a mistake.

7. I do not mind taking risks even though I might make mistakes.

8. I enjoy writing compositions.

9. To write a composition in English, I think of the major ideas in my language, and then, I translate them into English.

10. I consider that I understand a word in English when I find the equivalence in my language.

11. In my compositions, I prefer to use sentences that I have learned by heart.

12. When I write in English, I have both languages present in my mind.

13. When I make errors in English, it is because of my language.

14. I compare both languages.

15. I translate from my language into English.

Using the criteria of "always," "often," "sometimes," and "never," the learners' perception indicated an "often" (13/15) answer to most of the questions. The answer "sometimes" also had a high rate. The "always" answer was moderate, and the "never" answer was very rare. These results indicate L1 was continuously present in learning and using L2. 


\section{Interview}

The interview was prepared with questions related to the way learners process LL2 or understand their learning process and their use of L2. Its purpose was to validate or invalidate the information obtained on the questionnaire about the strategies used to cope with the learning and the use of L2.

1. Are there any errors you make in English that you know they come from the influence of your native language?

2. Have you noticed any differences between English and your language?

3. When you hear or see a new word in English, and you do not know the meaning, what do you do in your mind?

4. Would you say you think in English?

5. How would you see both languages in your brain? a) Both together, b) separate, c) independent but with a portion mixed, d) one bigger than the other?

For the first question, six out of seven learners stated the errors came from the influence of their L1. All of them had noticed differences between English (L2) and their L1. All learners tried to understand the new word from the context of the conversation. Five out of seven learners claimed they think in English, and two of them declared to do it sometimes. Six learners out of seven considered their mother tongue takes a bigger space in their brain than English. One of the learners stated English (L2) takes a bigger space in her brain than her mother tongue (L1). These results show all of them have compared both languages and have established the similarities and differences between L1 and L2.

\section{Conclusions}

Examining the influence of L1 in LL2 might yield new insights beyond those currently noted by theorists and teachers. The MT strategy begins as a comparison strategy executed by the intelligence to establish the equivalences and the differences between L1 and L2 at all linguistic levels. The learners create their "translational zone," and it is in this zone they put the result of these comparisons. The MT strategy is active as long as the equivalences and differences between the two languages are established. The frequent use of the MT strategy makes it automatic, and it becomes an MT product. The MT product, which are the elements put in the translational zone, becomes a procedural knowledge, stored in the long-term memory; the learners will retrieve automatically and unconsciously the information from their translational zone to write in L2. However, if the learners cannot find the equivalences in the translational zone, they will again use the MT strategy to compare L1 and L2 and to establish new equivalences and differences. The automaticity could stop if there were a substantial change in the frequency of contact or use of L2. The comparison between L2 and L1 creates an awareness at the linguistic level not only of L2 but also of L1. In a certain way, this could explain the fact that a learner uses L2 when s/he learns a third language (L3). The similarities and differences between L 2 and L1 are already in the memory. The MT strategy could make other comparisons between L1 and L3 and between L2 and L3. The learner will add the results of these comparisons to his/her translational zone. These new comparisons will also be stored in long-term memory. To write in L2, the learner will again retrieve the information from his/her larger translational zone.

In the Translational Hypothesis, Bibeau (1979) stated the learner doubles the maternal tree, and eventually the learner experiences a linguistic polarity where the foreign tree gradually takes the place of the maternal tree. The results of this study indicate the learner creates a translational zone. 
In this translational zone, there are the differences and similarities between the two languages, but the foreign tree would not take the place of the maternal tree. There would be a space shared by both languages (Translational Zone), but L1 and L2 would have an independent space in the brain of the learner. They express the idea of L1 taking "a bigger place" in their brain. It could be interesting to determine in a future research study if fully bilinguals experience the linguistic polarity, where the foreign language takes the place of L1.

\section{Implications}

On inserting the concept of MT in LL2, it would be naïve to pretend to elucidate, in its entirety, a process as complex as learning a second language, but if MT is present in LL2, how can we take advantage of this situation? If the MT plays a role in LL2, teachers and learners should not fight against MT, thinking learners will learn faster if they do not translate is not the solution. The comparisons take place anyhow. It would be more important to help them to find the right equivalences so the number of errors might decrease.

\section{Further Research}

Other questions which may emerge from this research are as follows. How can we help students who immigrate to Canada and who attend schools without having sufficient knowledge of English? How could we help them deal with learning outcomes prepared for students who have English as L1? More research in this area will help teachers and students cope better with the process of teaching and learning English as a Second Language in the Canadian educational system.

\section{References}

Al-Khuli, M. (1979). A contrastive transformational grammar: Arabic and English. Leiden, Holland: E. J. Brill. Alhaysony, M. (2012). An analysis of article errors among Saudi female EFL students: A case study. Asian Social Science, 8(12), 55-66. doi.org/10.5539/ass.v8n12p55

Anderson, J. R. (1983). The architecture of cognition. Cambridge, MA: Harvard University Press.

Anderson, J. R. (1985). Cognitive psychology and its implications. New York, NY: W.H. Freeman.

Anderson, J. R. (1992). Automaticity and the ACT theory. American Journal of Psychology, 105(2), $165-180$. doi.org/10.2307/1423026

Bauman, N. (2007). A catalogue of errors made by Korean learners of English. Advancing ELT: Empowering teachers, empowering learners. Proceedings of the $14^{\text {th }}$ Annual KOTESOL International Conference (pp. 167-176). Seoul, Korea.

Bialystok, E. (1982). On the relationship between knowing and using linguistic forms. Applied Linguistics, 3(3), 181-206. doi.org/10.1093/applin/3.3.181

Bibeau, G. (1979). Hypothèse psycholinguistique sur l'apprentissage d'une langue étrangère [Psycholinguistic hypothesis on learning a foreign language]. In G. Rondeau, G. Bibeau, G. Gagné, \& G. Tagart. Vingt-cinq ans de linguistique au Canada : hommage à Jean-Paul Vinay par ses anciens élèves. [Twenty-five years of linguistics in Canada] (pp. 399-414). Montréal, Canada: Centre Éducatif et Culturel.

Bley-Vroman, R. W., Felix, S. W., \& Loup, G. L. (1988). The accessibility of universal grammar in adult language Learning. Second Language Research, 4(1), 1-32. doi:10.1177/026765838800400101

Bondarenko, O. (2014). Does Russian English exist? American Journal of Educational Research, 2(9), 832-839. doi.org/10.12691/education-2-9-20

Bruner, J.S. (1975). Language as an instrument of thought. In A. Davies (Eds.), Problems of language and learning (pp. 50-72). London, England: Heinemann.

Bryant, W. (1984). Typical errors in English made by Japanese ESL students. Jalt-publications.org. Retrieved from https://jalt-publications.org/files/pdf-article/art1_21.pdf

Cardu, B. (1996). Pour un cerveau catégoriel. Theorie dé l'emergence et relation cerveau-pensée [A category brain; Emergence Theory and relationships between brain and thought]. Montréal, Canada: Les Presses de l'Université de Montréal. 
Falla-Wood: The role of mental translation in learning and using a second/foreign language by female adult learners

Carrió-Pastor, M. L. (2012). A contrastive analysis of epistemic modality in scientific English. Revista de Lenguas para fines específicos [Journal for languages for specific purposes], 19, 15-132.

Carrió-Pastor, M. L., \& Mestre-Mestre, E. M. (2014). Lexical errors in second language scientific writing: some conceptual implications. International Journal of English Studies, 14(1), 97-108. doi.org/10.6018/ijes/14/1/154361

Changeux, J. P. (1998). Plasticité cérébrale et apprentissage [Brain plasticity and learning]. Pour la Science [For Science], 254, 86-91.

Cheng, X. (2015). Interlanguage-based error analysis in higher vocational and technological college EFL education in China. Journal of Language Teaching and Research, 6(3), 639-649. doi.org/10.17507/j1tr.0603.22

Chomsky, N. (1965). Aspects of the theory of syntax. Cambridge, MA: MIT Press.

Chomsky, N. (1976). Reflections on language. London, England: Temple Smith.

Chomsky, N. (1980a). Rules and representations. New York, NY: Columbia University Press.

Chomsky, N. (1980b). On cognitive structures and their development: A reply to Piaget. In M. Piatelli-Palmarini (Ed.), Language and learning (Chapter 49, pp. 393-398). London, England: Routledge \& Kegan.

Clahsen, H. (1990). The Comparative study of first and second language development. Studies in Second Language Acquisition, 12(2), 103-116. Doi: 10.1017/s0272263100009050

Cohen, A. D. (1995). The role of language thought in foreign language learning. Working Papers in Educational Linguistics, 11(2), 1-11.

Cohen, A. D., \& Hawras, S. (1996). Mental translation into the first language during foreign-language reading. The Language Teacher, 20(2), 6-12.

Conti, G. (2004). Metacognitive enhancement and error correction: An investigation in the impact of selfmonitoring strategies on L2 Italian student writing (Doctoral dissertation). University of Reading. Berkshire, United Kingdom.

Dirix, N., \& Duyck, W. (2017). The first- and second-language age of acquisition effect in first- and secondlanguage book reading. Journal of Memory and Language, 97, 103-120. doi.org/10.1016/j.jml.2017.07.012

Dulay, H., \& Burt, M. (1973). Should we teach children syntax? Language Learning, 23(2), 245-258. doi.org/10.1111/j.1467-1770.1973.tb00659.x

Dulay, H., \& Burt, M. (1974). Natural sequences in child second language acquisition. Language Learning, 24(1), 37-53. doi.org/10.1111/j.1467-1770.1974.tb00234.x

El-Sayed, A. M. (1982). An investigation into the syntactic errors of Saudi freshmen's English compositions. Indiana County, PA: University of Pennsylvania.

Ellis, N. (2002). Frequency effects in language processing: A review with implications for theories of implicit and explicit language acquisition. Studies in Second Language Acquisition, 24(2), 143-188. doi: 10.1017/S0272263102002024

Ellis, R. (1985). Understanding second Language acquisition. Oxford, England: Oxford University Press.

Ellis, R. (1994) The study of second language acquisition. Oxford, England: Oxford University Press.

Ellis, R. (2004). The definition and measurement of L2 explicit knowledge. Language Learning, 54(2), 227-275.

Epstein, D. S., Flynn, S., \& Martohardjono, G. (1996). Second language acquisition: Theoretical and experimental issues in contemporary research. Behavioral and Brain Sciences, 19, 677-758.

Faerch, C., \& Kasper, G. (1985). Procedural knowledge as a component of foreign language learners' communicative competence. In H. Bolte \& W. Herrlitz (Eds.), Kommunikation in Sprachnterricht. [Pragmatic Competence], (pp. 169-99). Utrecht, Holland: University of Utrecht.

Faerch, C., \& Kasper, G. (1986). Perspectives on language transfer. Applied Linguistics, 7(2), 111-136.

Faerch, C., \& Kasper, G. (1987). Introspection in second language research. Clevedon, England: Multilingual Matters.

Falla-Wood, J. (2017). Errors in second/foreign language learning and their interpretations. Education and Linguistic Research, 3(1), 1-14. doi.org/10.5296/elr.v3i1.10251

Flynn, S. (1984). A universal in L2 acquisition based on a PBD typology. In F. Eckman, L. Bell, \& R. D. Nelson (Eds.), Universals of Second Language Acquisition. Rowley, MA: Newbury House.

Flynn, S. (1987). A parameter-setting model of L2 acquisition. Studies in Theoretical Psycholinguistics, 5, 59-81. Dordrecht, Holland: D. Reidel Publishing Company. doi.org/10.1007/978-94-009-3747-5

Gardner, H. (1993). Frames of mind: The theory of multiple intelligences $\left[10^{\text {th }}\right.$ anniversary edition]. New York, NY: Basic Books.

Hawkins, R. (2001). Second Language Syntax: A Generative Introduction. Oxford, England: Blackwell.

Hong G. S. (1980). Contrastive analysis, error analysis and interlanguage in relation to adult Chinese Speakers learning English as a second language (Doctoral Dissertation). Simon Fraser University, BC, Canada. Retrieved from summit.sfu.ca/system/files/iritems1/3917/b12509668.pdf 
Jiang, N. (2004). Semantic transfer and its implications for vocabulary teaching in a second language. The Modern Language Journal, 88(3), 416-432. doi.org/10.1111/j.0026-9902.2004.00238x

Kern, R. (1994). The role of mental translation in second language reading. Studies in Second Language Acquisition, 16, 441-461.

Köhlmyr, P. (2003). To Err is human...: An investigation of grammatical errors in Swedish 16-year-old learners' written production in English (Doctoral Dissertation). Acta Universitatis Gothoburgensis, Göteborg.

Krashen, S. (1981). Second language acquisition and second language learning. Oxford, England: Pergamon.

Krashen, S. (1982). Principles and practice in second language acquisition. Oxford, England: Pergamon.

Krashen, S. (1983). Newmark's ignorance hypothesis and current second language acquisition theory. In S.M. Gass, \& L. Selinker (Eds). Language Transfer in Language Learning (pp. 135-53). Rowley, MA: Newbury House.

Lanteigne, B. (2006). Common, persistent errors in English by Brazilian Portuguese speakers. TEFL Web Journal, 4(1). Retrieved from www.academia.edu/761700/Common_persistent_errors_in_English_by_Brazilian_Portugese_speakers

Lardiere, D. (2009). Some thoughts on the contrastive analysis of features in second language acquisition. Second Language Research, 25(2), 173-227. doi.org/10.1177/0267658308100283

Laroche, S. (1998). Les mécanismes de la mémoire [Mechanisms of memory]. Pour la Science [For Science], 254, 94-101.

Lennenberg, E. (1967). Biological foundation of language. New York, NY: Wiley and Sons.

Liceras, J. (1988). L2 learnability: Delimiting the domain of core grammar as distinct from the marked periphery. In S. Flynn \& W. O’Neil (Eds.), Linguistic Theory in Second Language Acquisition (pp. 199-224). Dordrecht, Holland: Kluwer.

Lixin, X. (2015). An error analysis of the word class: A case study of Chinese college students. International Journal of Emerging Technologies in Learning, 10(3), 41-45. doi.org/10.3991/ijet.v10i3.4563

Mac Whinney, B., Bates, E., \& Kliegl, R. (1984). Cue validity and sentence interpretation in English, German, and Italian. Journal of Verbal Learning and Verbal Behaviour, 23(2), 127-150. doi.org/10.1016/S00225371(84)90093-8

Macaro, E. (2006). Strategies for language learning and for language use: Revising the theoretical framework. The Modern Language Journal, 90(3), 320-337.

McLaughlin, B. M. (1987). Theories of second language learning. London, England: Edward Arnold.

Meisel, J. (1997). The acquisition of the syntax of negation in French and German: Contrasting first and second language development. Second Language Research, 13(3), 227-263. doi:10.1191/026765897666180760

Miele, F. (2002). Intelligence, race, and genetics. Oxford, England: Westview Press.

Miliander, J. (2003). We get the answer we deserve. A study of vocabulary in a spoken and written corpus of advanced learner English. (Doctoral Dissertation). Karlstad, Sweden: Karlstad University.

Miller, G. A. (1956). The magical number seven, plus or minus two: Some limits of our capacity for processing information. Psychological Review, 63, 81-97.

Mourssi, A. (2013). Cross linguistic influence of L1 (Arabic) in acquiring linguistic items of L2 (English): An empirical study in the context of Arab learners of English as undergraduate learners. Theory and Practice in Language Studies, 3(3), 397-403. doi.org/10.4304/tpls.3.3.397-403.

Nyikos, M. \& Oxford, R. (1993). A factor analytic study of language learning strategy use: Interpretations from information-processing theory and social psychology. The Modern Language Journal, 77(1), 11-22.

O’Malley, J. M., and Chamot, A. (1990). Learning strategies in second language acquisition. Cambridge, England: Cambridge University Press. doi.org/10.1017/CBO9781139524490

O’Malley, J. M., Chamot, A. U., Stewner-Manzanares, G., Küpper L., \& Russo, R. P. (1985a). Learning strategies used by beginning and intermediate ESL students. Language Learning, 34(1), 21-46. doi.org/10.1111/j1467-1770.1985.tb01013.x

O’Malley, J. M., Chamot, A. U., Stewner-Manzanares, Russo, R. P., \& G., Küpper L. (1985b). Learning strategy applications with students of English as a second language. TESOL Quarterly, 19, 285-96. doi.org/10.2307/3586278

O’Malley, J. M., Chamot, A.U., \& Walker, C. (1987). Some applications of cognitive theory to second language acquisition. Studies in Second Language Acquisition, 9, 287-306. doi.org/10.1017/S02772263100006690

Odlin, T. (1989). Language transfer. Cambridge, England: Cambridge University Press.

Pavlenko, A. (2011). Thinking and speaking in two languages. Bristol, England: Multilingual Matters.

Piaget, J. (1961). La psychologie de l'intelligence. [The psychology of intelligence] Paris, France: Armand Colin. 
Piatelli-Palmarini, M. (1979). Théories du langage, théories de l'apprentissage : le débat entre Jean Piaget et Noam Chomsky [Theories of language, theories of learning: A debate between Jean Piaget and Noam Chomsky]. Paris, France : Seuil.

Plomin, R., \& Spinath, F. (2004). Intelligence: Genetics, genes, and genomics. Journal of Personality and Social Psychology, 86(1), 112-129. doi.org/10.1037/0022-3514.86.1.112.

Preston, D. (1989). Sociolinguistics and second language acquisition. Oxford, England: Blackwell.

Rabinowitz, M. \& Chi, M. T. (1987). An interactive model strategic processing. In S. J. Ceci (Ed.), Handbook of cognitive, social and neuropsychological aspects of learning disabilities (vol. 2, pp. 82-103. Hillsdale, NJ: Erlbaum.

Rosén, C. (2006). Warum klingt das nicht deutsch? : Probleme der Informationsstrukturierung in deutschen Texten schwedischer Schüler und Studenten [Why does not that sound German?: Problems of information structuring in German texts of Swedish students] (Doctoral Dissertation). Lund University, Stockholm.

Rozovskaya, A., Roth, D (2010). Training paradigms for correcting errors in grammar and usage. In Proceedings of human language technologies, conference of the North American of the Association for Computational Linguistics (pp. 154-162). Los Angeles, CA.

Schachter, J. (1989). Testing a proposed universal. In S. Gass \& J. Schachter (Eds.), Linguistic Perspectives on Second Language Acquisition (pp. 1-6). Cambridge, England: Cambridge University Press.

Schachter, J. (1992). A new account of language transfer. In S. Gass \& L.Selinker (Eds.), Language Transfer in Language Learning (pp. 32-46). Philadelphia, PA: John Benjamins.

Schmidt, R. (1990). The Role of Consciousness in Second Language Learning. Applied Linguistics, 11(2), 129-158. doi.org/10.1093/applin/11.2.129

Schmidt, R. (1994). Deconstructing consciousness in search of useful definitions for applied linguistics. AILA Review, 11, 11-16.

Selinker, L. (1972). Interlanguage. International Review of Applied Linguistics, 10, 209-31.

Sharwood-Smith, M., \& Kellerman, E. (1986). Cross-linguistic influence in second language acquisition: An introduction. In E. Kellerman \& M. Sharwood-Smith (Eds.), Cross-linguistic Influence in Second Language Acquisition (pp. 10-20). Oxford, England: Pergamon.

Slobin, D. I. (1973). Cognitive prerequisites for the development of grammar. In C. H. Ferguson, \& D. I. Slobin, (Eds.), Studies of Child Language Development (pp.175-276). New York, NY: Holt, Rinehart and Winston. Spearman, C. (1904). General intelligence: Objectively determined and measured. The American Journalof Psychology, 13, 201-293. doi.org/10.2307/1412107

Squire, L. R. (2004) Memory systems of the brain: A brief history and current perspective. Neurobiology of Learning and Memory, 82, 171-177. doi.org/10.1016/j.nin.2004.06.005

Sternberg, R. J. (1985). Beyond IQ: A triarchic theory of human intelligence. Cambridge, England: Cambridge University Press.

Tassin, J. P. (1998). Qu'est-ce que l'intelligence? [What is intelligence?], Pour la Science [For Science]. 254. 86-91.

Tomlin, R. (1990). Functionalism in Second Language Acquisition. Studies in Second Language Acquisition, 12, 155-177. doi.org/10.1017/s0272263100009062

Towell, R., \& Hawkins, R. (1994). Approaches to Second Language Acquisition. Bristol, England: Multilingual Matters Longdunn Press.

Ullman, M.T. (2001). The declarative/procedural model of lexicon and grammar. Journal of Psycholinguistic Research, 30(1), 37-69. doi.org/10.1023/A:1005204207369

Watson, P., Paul, E., Cooke, G., Ward, N., Monti, J., \& Horecka, K. (2016). Underlying sources of cognitiveanatomical variation in multi-modal neuroimaging and cognitive testing. Neuroimage, 129, 439-449. doi.org/10.1016/j.neuroimage.2016.01.023

White, L. (1986). Implications of parametric variation for adult second language acquisition: An investigation of the pro-drop parameter. In V. Cook (Ed.), Experimental approaches to second language acquisition (pp. 5572). Oxford, England: Pergamon. White, L. (1985). The pro-drop parameter in adult second language acquisition. Language Learning, 35, 47-62. doi.org/10.1111/j.1467-1770.1985.tbo1014.x

Ye, Z. (2004). Chinese categorization of interpersonal relationships and the cultural logic of Chinese social interaction: An indigenous perspective. Intercultural Pragmatics, 1(2), 211-230. doi.org/10.1515/iprg.2004.1.2.211

Zhang, Q. (2010). A Study of Chinese learning of English tag questions. Journal of Language Teaching and Research, 1(5), 578-582. doi.org/10.4304/jltr.1.5.578-582

Zheng, C., \& Park, T. (2013). An analysis of errors in English writing made by Chinese and Korean university students. Theory and Practice in Language Studies, 3(8), 1342-1351. doi.org/10.4304/tpls.3.8.1342-1351 